\title{
Analisis Peran Budaya Sekolah yang Religius dalam Pembentukan Karakter Siswa
}

\author{
Fella Silkyanti \\ Jurusan Pendidikan Guru Sekolah Dasar \\ Fakultas Ilmu Pendidikan \\ Universitas PGRI Semarang \\ e-mail: silkyantifella@gmail.com
}

\begin{abstract}
Abstrak
Sekolah perlu menyadari keberadaan peran budaya sekolah akan memengaruhi dalam pembentukan karakter pada siswa. Dengan adanya berbagai penyimpangan karakter pada siswa, diharapkan melalui budaya sekolah siswa dapat membentuk karakter melalui suatu pembiasaan yang dilakukan disekolah. Tujuan penelitian ini adalah untuk mengetahui Peran Budaya Sekolah Yang Religius Dalam Pembentukan Karakter Siswa di SD Muhammadiyah 17 Semarang. Penelitian ini merupakan penelitian kualitatif dengan menggunakan pendekatan deskriptif. Teknik penelitian yang dilakukan adalah melalui wawancara, angket, observasi, dan dokumentasi. Hasil penelitian sebagai berikut. 1) Budaya sekolah religius di SD Muhammadiyah 17 Semarang setiap harinya meliputi budaya senyum, salam, sapa, sopan dan santun atau 5S, do'a bersama, hafalan, TPQ, sholat dhuha dan sholat dhuhur. 2) Metode atau langkah dalam membentuk karakter melalui keteladanan dan pembiasaan. 3) Karakter yang dihasilkan adalah religius, disiplin, toleransi, bersahabat, dan tanggung jawab. Dalam penelitian tersebut menyatakan bahwa peran budaya sekolah religius dapat membentuk karakter pada siswa.
\end{abstract}

Kata kunci: Budaya Sekolah Religius, Karakter

\begin{abstract}
Schools need to be aware that the role of school culture will influence the formation of character in students. With the existence of various character deviations in students, it is expected that through school culture students can shape character through a habit that is done in school.. The purpose of fftthis study was to determine the Role of Religious School Culture in the Formation of Student Characters at Muhammadiyah Elementary School 17 Semarang. This research is a qualitative study using a descriptive study approach. The research technique used is through interviews, observation, and documentation. The results of the study are as follows. 1) The culture of religious schools in Muhammadiyah Elementary School 17 Semarang every day includes a culture of smile, greetings, greetings, polite and polite, 5S together, memorizing, $T P Q$, Dhuha prayer and dhuhur prayer. 2) Method or step in forming character through exemplary and habituation. 3) The characters produced are religious, disciplined, tolerant, independent, friendly, and responsible. In the study stated that the role of religious school culture can shape the character of students.
\end{abstract}

Keywords: Religious School Culture, Characte 


\section{Pendahuluan}

Pendidikan memiliki peranan penting dalam kehidupan manusia. Dalam pendidikan merupakan sebuah usaha terencana yang dilakukan agar memiliki softskill dan hardskill. Softskill berupa kemampuan dalam bersikap yang sesuai dengan norma agama, norma adat, norma susila, dan norma lainnya. Sedangkan hardskill berupa pengetahuan dan keterampilan yang dimiliki oleh anak. Pemberian pendidikan karakter tidak hanya dilakukan melalui pendidikan keluarga saja, melainkan pendidikan karakter dapat dilakukan melalui pendidikan disekolah. Menurut Jalaludin (2012) Pendidikan adalah usaha sistematis dengan penuh kasih untuk membangun peradaban bangsa. Di balik sukses ekonomi dan teknologi yang ditunjukkan negara-negara maju, semua itu semula disemangati nilai-nilai kemanusiaan agar kehidupan bisa dijalani lebih mudah, lebih produktif, dan lebih bermakna. Namun banyak masyarakat yang lalu gagal menjaga komitmen kemanusiaannya setelah tetapi jabatan dan kekayaan, meski diraih dengan cara tidak terhormat dan melanggar aturan.

Menurut Yusuf (2013) dalam Kamus Inggris-Indonesia yang ditulis oleh John M. Echols dan Hassan Shadily menyebutkan bahwa karakter berasal dari bahasa Inggris yaitu character yang berarti watak, karakter, atau sifat. Dalam Kamus Psikologi sebagaimana dikutip oleh M. Furqon Hidayatullah dalam buku Guru Sejati: Membangun Insan Berkarakter Kuat dan Cerdas dinyatakan bahwa karakter adalah kepribadian ditinjau dari titik tolak etis atau moral, misalnya kejujuran seseorang, biasanya berkaitan dengan sifat-sifat yang tetap. Secara istilah, karakter diartikan sebagai sifat manusia pada umumnya dimana manusia mempunyai banyak sifat yang tergantung pada kehidupan sendiri. Karakter adalah sifat kejiwaan, akhlak, atau budi pekerti yang menjadi ciri khas seseorang atau sekelompok orang. Defenisi dari "The stamp of individually or group impressed by nature, education or habit." Karakter merupakan nilai-nilai perilaku manusia yang berhubungan dengan Tuhan Yang Maha Esa, diri sendiri, sesama manusia, lingkungan, dan kebangsaan yang terwujud dalam pikiran, sikap, perasaan, perkataan, perbuatan berdasarkan norma-norma agama, hukum, tata krama, budaya, dan adat istiadat. Karakter dapat juga diartikan sama dengan akhlak dan budi pekerti, sehingga karakter bangsa identik dengan akhlak bangsa atau budi pekerti bangsa. Bangsa yang berkarakter adalah bangsa yang berakhlak dan berbudi pekerti, sebaliknya bangsa yang tidak berkarakter adalah bangsa yang tidak atau kurang berakhlak atau tidak memiliki standar norma perilaku yang baik. Sementara itu pengertian karakter menurut Pusat Bahasa Depdiknas adalah "bawaan, hati, jiwa, kepribadian, budi pekerti, perilaku, personalitas, sifat, tabiat, temperamen, watak". Adapun berkarakter adalah berkepribadian, berperilaku, bersifat, bertabiat dan berwatak". Menurut Tadkiroatun Musfiroh (UNY, 2008), karakter mengacu kepada serangkaian sikap (attitude), perilaku (behavior), motivasi (motivation) dan keterampilan (skill). Karakter berasal dari kata Yunani yang berarti "to mark" atau menandai dan memfokuskan bagaimana mengaplikasikan nilai kebaikan dalam bentuk tindakan atau tingkah laku sehingga orang yang tidak jujur, kejam, rakus dan perilaku jelek lainnya dikatakan orang berkarakter jelek. Sebaliknya, orang yang perilakunya sesuai dengan kaidah moral disebut dengan berkarakter mulia.

Menurut Omeri (2015) pendidikan karakter, sekarang ini mutlak diperlukan bukan hanya di sekolah saja, tapi dirumah dan di lingkungan sosial. Bahkan sekarang ini peserta pendidikan karakter bukan lagi anak usia dini hingga remaja, tetapi juga usia dewasa. Mutlak perlu untuk kelangsungan hidup Bangsa ini.Pendidikan karakter adalah suatu sistem penamaan nilai-nilai karakter yang meliputi komponen pengetahuan, kesadaran atau kemauan, dan tindakan untuk melaksanakan nilai-nilai tersebut, baik terhadap Tuhan Yang Maha Esa, diri sendiri, sesama, lingkungan, maupun kebangsaan. Pengembangan karakter bangsa dapat dilakukan melalui perkembangan karakter individu seseorang.Akan tetapi, karena manusia hidup dalam lingkungan sosial dan budaya tertentu, maka perkembangan karakter individu seseorang hanya dapat dilakukan dalam lingkungan sosial dan budaya yang bersangkutan. Artinya, perkembangan budaya dan karakter dapat dilakukan dalam suatu proses pendidikan yang tidak melepaskan peserta didik dari lingkungan sosial,budaya masyarakat, dan budaya bangsa.Lingkungan sosial dan budaya bangsa adalah Pancasila, jadi pendidikan budaya dan karakter adalah mengembangkan nilai-nilai Pancasila pada diri peseta didik melalui pendidikan hati, otak, dan fisik. sejak awal munculnya pendidikan oleh para ahli dianggap sebagai suatu hal yang niscaya.John Sewey, misalnya, pada tahun 1916 yang mengatakan bahwa sudah merupakan hal yang lumrah dalam teori pendidikan bahwa pembentukan watak merupakan tujuan umum pengajaran dan pendidikan budi pekerti di sekolah. Menurut Novan Ardy Wiyani (2012:43) bahwa Pendidikan karakter merupakan sebuah proses pemberian tuntunan yang 
diberikan kepada peserta didik agar menjadi manusia yang berkarakter. Pendidikan karakter memerlukan keteladanan mulai sejak dini sampai dewasa. Jadi sangat penting, bagi pengelola sekolah dan guru untuk menanamkan nilai-nilai dasar, tidak hanya saja hafalan tetapi juga menantang siswa untuk menerapkannya dalam sehari-hari mengenai hal dalam lingkungan sekolah maupun diluar. Pendidikan yang dilakukan dapat membentuk kepribadian dan karakter peserta didik menjadi lebih baik dan memiliki makna dalam kehidupannya. Seperti halnya pendidikan karakter tercermin di dalam pasal 3 Undang-Undang Nomor 20 Tahun 2003 tentang sistem pendidikan nasional yaitu "Pendidikan nasional berfungsi mengembangkan kemampuan dan membentuk watak serta beradaban bangsa yang bermartabat dalam rangka mencerdaskan kehidupan bangsa, berrtujuan untuk mengembangkan potensi peserta didik agar menjadi manusia yang beriman dan bertaqwa kepada Tuhan yang Maha Esa, berakhlak mulia, sehat berilmu, cakap, kreatif, mandiri, dan menjadi warga negara yang demokratis serta bertanggung jawab".

Namun, dalam kenyataan di lapangan fungsi pembentukan karakter yang diharapkan dalam pendidikan nasional belum terwujud secara optimal, meskipun penanaman nilai karakter sudah terlaksana akan tetapi masih ditemukan peserta didik di sekolah yang tidak menaati peraturan disekolah dan berdampak pada karakter yang dimiliki oleh peserta didik. Dalam berbagai tingkah laku yang diterima oleh siswa tersebut akan dibawa dan diterapkan dalam kehidupan sehari-hari. Khususnya akan dibawa kesekolah dan akan menimbulkan pelanggaran peraturan sekolah diantaranya seperti berkata kasar terhadap teman maupun guru, bullying, pembohongan terhadap guru. Hal itu akan memengaruhi teman-teman sekitar serta dapat membuat peserta didik lainnya mengikuti pelanggaran peraturan sekolah. Lingkungan sangat mempengaruhi karakter seorang anak apabila anak tumbuh dilingkungan yang baik maka anak akan tumbuh dengan karakter yang baik, tetapi akhir akhir ini dikarenakan tumbuhnya perkembangan teknologi yang semakin canggih dan kurang adanya pengawasan yang lebih untuk itu perlunya pendidikan karakter yaitu untuk membantu siswa supaya memiliki kebiasaan dan perilaku baik dalam kehidupan sehari harinya baik dirumah, sekolah maupun masyarakat.

Tindakan-tindakan tersebut seolah sudah menjadi suatu hal yang wajar untuk dilakukan padahal sikap atau tindakan itu merupakan perbuatan yang salah. Maka dari itu sekolah yang merupakan salah satu lembaga penanaman nilai karakter mengoptimalkan pendidikan karakter peserta didik untuk menjadi lebih baik. Salah satunya yaitu karakter dapat ditanamkan pada siswa disekolah dengan melibatkan seluruh warga sekolah agar siswa dapat mencontoh kebiasaan-kebiasaan yang positif yang dilakukan disekolah. Pentingnya peran guru dalam membentuk karakter anak sangat membantu perilaku anak.Untuk itu perlu adanya penanaman karakter disekolah yang dilakukan dengan baik oleh pihak sekolah salah satunya melakukan pembiasaan disekolah yaitu menerapkan budaya sekolah. Pembentukan budaya sekolah berbasis karakter dapat dilakukan melalui kegiatan rutin yang dilaksanakan antar keterlibatan semua warga sekolah. Seperti halnya menurut Daryanto (2015:6) Budaya sekolah adalah sekumpulan norma, nilai dan tradisi yang telah dibangun dalam waktu yang lama oleh semua warga sekolah dan mengarah ke seluruh aktivitas personel budaya. Implementasi pendidikan karakter di sekolah mengarah pada pembentukan budaya sekolah yaitu nilai-nilai yang melandasi perilaku, tradisi, kebiasaan sehari-hari, serta berbagai simbol yang dipraktikan oleh seluruh warga sekolah dan masyarakat sekitarnya. Hal ini menunjukkan bahwa budaya sekolah mempunyai pengaruh besar terhadap proses pencapaian keberhasilan dalam pendidikan karakter. Dapat dimaknai juga bahwa pendidikan karakter mempunyai peran untuk menjadi bagian dalam budaya sekolah yang positif.

Pendidikan karakter berbasis nilai religius juga dapat diistilahkan dengan pendidikan karakter berbasis agama. Penidikan karakter berbasis agama merupakan pendidikan yang menegembangkan nilai-nilai yang berdasarkan agama yang membentuk kepribadian, sikap, dan tingkah laku yang utama atau luhur dalam kehidupan. Nilai religius tersebut dapat dibentuk melalui budaya sekolah sehingga budaya sekolah yang diterapkan dalam pembentukan karakter merupakan budaya sekolah yang religius.

Menurut Teng (2017) kebudayaan merupakan hasil interaksi kehidupan bersama. Manusia sebagai anggota masyarakat senantiasa mengalami perubahan-perubahan. Suatu gerak konjungsi atau perubahan naik turunnya gelombang kebudayaan suatu masyarakat dalam kurun waktu tertentu disebut dinamika kebudayaan. Dalam proses perkembangannya, kreativitas dan tingkat peradaban masyarakat sebagai pemiliknya sehingga kemajuan kebudayaan yang ada pada suatu masyarakat sesungguhnya merupakan suatu cermin dari kemajuan peradaban masyarakat tersebut. Perbedaan mendasar yang menempatkan manusia sebagai makhluk yang tertinggi adalah manusia memiliki budi atau akal pikiran sehingga 
manusia menjadi satusatunya makhluk hidup yang memiliki kemampuan menciptakan hal-hal yang berguna bagi kelangsungan kehidupannya (makhluk berbudaya). Manusia harus beradaptasi dengan lingkungannya untuk mengembangkan pola-pola perilaku yang akan membantu usahanya dalam memanfaatkan lingkungan demi kelangsungan hidupnya. Manusia juga membuat perencanaan-perencanaan untuk memecahkan masalah-masalah dalam kehidupan. Semua yang dihasilkan dan diciptakan oleh manusia dalam memenuhi berbagai kebutuhan hidup itu disebut kebudayaan. Ketika berbicara mengenai budaya, kita harus mau membuka pikiran untuk menerima kritikan dan banyak hal baru. Budaya bersifat kompleks, luas dan abstrak. Budaya tidak terbatas pada seni yang biasa dilihat dalam gedung kesenian atau tempat bersejarah, seperti museum. Tetapi, budaya merupakan suatu pola hidup menyeluruh. Budaya memiliki banyak aspek yang turut menentukan prilaku komunikatif. Kebudayaan sebagai kontradiksi antara immanensi7 dan transendensi8 dapat dipandang sebagai ciri khas dari kehidupan manusia seluruhnya. Arus alam itu berlangsung terus dalam diri manusia, tetapi di sini nampak suatu dimensi baru. Manusia tidak membiarkan diri begitu saja dihanyutkan oleh prosesproses alam, ia dapat melawan arus itu, ia tidak hanya mengikuti dorongan alam, tetapi juga suara hatinya. Melalui budaya sekolah yang religius diharapkan siswa dapat memiliki karakter, karena setiap siswa diwajibkan untuk bisa mengikuti kebiasaan yang dilaksanakan di sekolah tersebut. Jadi dengan adanya pembiasaan tersebut maka siswa akan terbisa melakukannya,sehingga terbentuklah karakter atau kepribadian dari siswa tersebut. Budaya sekolah yang baik maka akan menimbulkan budaya yang positif sehingga mendorong kebiasaan-kebiasaan sehari-hari yang dapat meningkatkan pembentukan karakter yang lebih baik.

Begitu juga di SD Muhammadiyah 17 Semarang, berdasarkan observasi, penanaman karakter di SD Muhammadiyah 17 Semarang dilakukan melalui budaya sekolah atau penanaman pembiasaan yang dilakukan sehari-hari pada saat diluar kelas maupun di dalam kelas. Budaya sekolah yang dilakukan di SD Muhammadiyah 17 Semarang dilakukan melalui Nilai Religius. Dengan penerapan nilai religius di dalam budaya sekolah tersebut sekolah dapat membentuk karakter siswa. Budaya sekolah di SD Muhammadiyah 17 Semarang seperti diterapkannya kegiatan menyapa bapak ibu guru pada pagi hari dengan berjabat tangan, sholat dhuha, hafalan, TPQ dan sholat dzuhur berjamaah dari kelas 1 sampai kelas 6 dan dibantu dengan kegiatan berbagai ekstrakurikuler.

Dari uraian latar belakang diatas peneliti melihat begitu pentingnya budaya sekolah yang religius dalam membantu membentuk karakter siswa. Maka dari itu peneliti tertarik untuk melakukan penelitian dengan judul "Analisis peran budaya sekolah yang religius terhadap pembentukan karakter siswa di SD Muhammadiyah 17 Semarang".

\section{Metode}

Jenis penelitian ini adalah penelitian kualitatif dengan menggunakan metode deskriptif. Menurut Sugiyono (2017: 9) Metode penelitian kualitatif merupakan metode penelitian yang berlandaskan pada filsafat postpositivisme, digunakan untuk meneliti pada kondisi obyek yang alamiah, peneliti adalah sebagai instrumen kunci, teknik pengumpulan data dilakukan secara tringulasi (gabungan), analisis data bersifat induktif/kualitatif, dan hasil penelitian kualitatif lebih menekankan makna daripada generalisasi. Sedangkan menurut Meleong (2014: 6) penelitian kualitatif adalah penelitian yang bermaksud untuk memahami fenomena tentang apa yang dialami oleh subyek penelitian misalnya perilaku, persepsi, motivasi, rindakan dan lain-lain secara holistik, dan dengan cara deskripsi dalam bentuk kata-kata dan bahasa, pada suatu konteks khusus yang alamiah dan memanfaatkan berbagai metode alamiah.

Menurut Meleong (2014:11) Dalam penelitain kualitatif, peneliti menggunakan penelitain kualitatif deskriptif. Dalam penelitian deskriptif kualitatif data yang dikumpulkan berupa katakata, gambar dan bukan angka-angka. Data tersebut berasal dari naskah wawancara, catatan lapangan, foto, video, dokumen pribadi, catatan atau memo, dan dokmen remsi lainnya.

Penelitian ini dilakukan di SD Muhammadiyah 17 Semarang yang terletak di Jalan Medoho Raya No.118, Kelurahan Sambirejo, Kecamatan Gayamsari, Kota Semarang, Jawa Tengah 50166.

Menurut Sugiyono (2015:137) mengatakan bahwa dilihat dari sumber datanya maka pengumpulan data dapat menggunakan sumber primer dan sumber sekunder. Sumber primer adalah sumber data yang langsung memberikan data kepada pengumpul data. Sedangkan sumber sekunder merupakan sumber yang tidak langsung memberikan data kepada pengumpul data, misalnya lewat orang lain atau lewat dokumen. Dalam penelitian ini, peneliti 
menggunakan sumber data primer dimana sumber data yang langsung memberikan data kepada pengumpul data.

Teknik yang digunakan adalah menggunakan wawancara, angket, observasi, dan dokumentasi. Pada tahap wawancara secara langsung dengan kepala sekolah, 4 guru, dan 20 siswa sebagai sample wawancara. Angket diambil 75 siswa sebagai sample dari setiap kelas. Observasi peneliti hanya mengamati, menguraikan, dan mendeskripsikan mengenai peran budaya sekolah religius dalam pembentukan karakter siswa di SD Muhammadiyah 17 Semarang. Dan dokumentasi dokumentasi sebagai bahan bukti dalam mencari informasi. Dokumentasi berupa foto, rekaman, ataupun video.

Sugiyono (2012:267) dalam penelitian kualitatif, kriteria utama terhadap data hasil penelitian adalah valid, reliabel dan obyektif. Validitas meruapakan derajat ketepatan antara data yang terjadi pada obyek penelitian dengan daya yang dapat dilaporkan oleh peneliti. Data yang valid adalah data yang tidak berbeda antar data yang dilaporkan oleh peneliti dengan data yang sesungguhnya terjadi pada obyek penelitian. Dan apabila peneliti membuat laporan yang tidak sesuai dengan apa yang terjadi pada obyek, maka data tersebut dapat dinyatakan tidak valid.

Analisis data menurut Sugiyono (2016:244) adalah proses mencari dan menyusun secara sistematis data yang diperoleh dari hasil wawancara, catatan lapangann, dan dokumentasi, dengan cara mengorganisasikan data ke dalam kategori, menjabarkan ke dalam unit-unit, melakukan sintesa, menyusun ke dalam pola, memilih mana yang penting dan yang akan dipelajari, dan membuat kesimpulan sehingga mudah dipahami oleh diri sendiri maupun orang lain.

Menurut Meleong (2010:127) ada tiga tahap kegiatan yang harus dilakukan oleh peneliti yaitu: a) Tahap pra-lapangan, meliputi menyusun rancangan penelitian, memilih lapangan penelitian, mengurus perizinan, menjajaki dan menilai lapangan, menyiapkan perlengkapan penelitian, dan persoalan etika penelitan, b) Tahap pekerjaan lapangan, meliputi memahami latar penelitian dan persiapan diri, memasuki lapangan, dan berperan serta sambil mengumpulkan data. Data tersebut diperoleh dengan observasi, wawancara, dokumentasi dan angket dengan cara menanyakan secara langsung kepada kepala sekolah, guru, serta siswa mengenai budaya sekolah religius dan karakter, dan c) Tahap analisis data, meliputi analisis data yang diperoleh melalui observasi, dokumentasi, kuesioner (angket) dan wawancara mengenai peran budaya sekolah religius yang ada di SD Muhammadiyah 17 Semrang dalam bentuk karakter siswa kepada kepala sekolah, guru serta siswa. Kemudian dilakukan penafsiran data sesuai dengan konteks permasalahan yang diteliti. Selanjutya pengecekan keabsahan data dengan cara mengecek sumber data yang didapat.

\section{Hasil dan Pembahasan}

SD Muhammadiyah 17 Semarang beralamat di Jalan Medoho Raya No.118, Kelurahan Sambrejo, Kecamatan Gayamsari, Kota Semarang.

Dari hasil wawancara dan observasi di SD Muhammadiyah 17 Semarang dikenal dengan kebiasaan budaya yang islaminya. Budaya sekolah yang dilakukan adalah pembiasaan senyum, salam, sapa, sopan, dan santun atau $5 \mathrm{~S}$, pembiasaan berdoa sebelum dan sebelum pembelajaran dan sesudah pembelajaran, hafalan, TPQ, Sholat dhuha dan sholat dhuhur berjamaah.

Budaya 5S (Senyum, Salam, Sapa, Sopan, dan Santun). Wujud lima nilai ini yaitu pada pagi hari ketika peserta didik masuk ke gerbang sekolah, semua guru sudah berjejer menyambut kedatangan peserta didik dengan memberikan senyuman, sapaan, salam, sopan dan santun kepada peserta didik ataupun orang tua/wali murid yang mengantar peserta didik ke sekolah. Dengan budaya 5S ini akan membuat peserta didik merasa lebih bahagia karena mereka merasa memiliki keluarga yang saling menyayangi. Berjabat tangan merupakan salah satu bentuk perilaku yang santun dan menghargai guru dan dapat membentuk karakter disiplin pada siswa karena siswa baris satu persatu secara bergantian untuk berjabat tangan terhadap guru. Hal ini sejalan dengan pendapat Asmaun Sahlan (2010:116) bahwa senyum, salam dan sapa dalam pandangan budaya menunjukkan bahwa dalam melakukan senyum,salam dan sapa dapat membuat kelompok masyarakat memiliki kedamaian, santun, saling tenggang rasa, toleran dan rasa hormat.

Selain itu, kegiatan siswa dipagi hari yaitu pembiasaan menaruh sepatu pada tempatnya dan sebelum memulai pada pembelajaran siswa melakukan baris berbaris terlebih dahulu. Menaruh sepatu dan sandal pada tempatnya merupakan kebiasaan yang berbeda dengan 
sekolah sekolah lain yang mana sekolah SD Muhammadiyah 17 Semarang menaruh sepatu didalam rak yang sudah ada di depan kelasnya Kegiatan ini dapat mengembangkan karakter kedisplinan dan tanggung jawab pada siswa. Dengan adanya budaya tersebut dapat membuktikan karakter kedisiplinan siswa, apabila siswa terbiasa menaruh sepatu dan sandal pada tempatnya dan dengan benar maka akan menjadi sebuah karakter yang baik pada siswa. Hal itu sejalan menurut Imas Kurniasih dan Berlin Sani (2017:138) bahwa disiplin merupakan tindakan yang menunjukkan perilaku tertib dan patuh pada berbagai ketentuan dan peraturan. Hal itu juga dilakukan pada kegiatan baris berbaris. Dimana dengan adanya baris berbaris siswa dapat masuk kelas satu persatu sesuai dengan urutan. Dengan adanya budaya tersebut dapat membuktikan karakter kedisiplinan siswa, apabila siswa terbiasa baris berbaris dan masuk kelas secara bergantian akan menjadi sebuah karakter disiplin pada siswa.

Hafalan merupakan kegiatan yang dilakukan setiap hari di SD Muhammahiyah 17 Semarang. Hafalan dilakukan dengan membaca surat bersama-sama di setiap kelas dari kelas 1 sampai kelas 6 . Pada pelaksanaan hafalan, didampingi oleh guru wali kelas masing-masing dan budaya ini sudah menjadi suatu kebiasaan siswa yang dilakukan disekolah setiap pagi hari. karakter tanggung jawab dapat dilihat ketika siswa dapat menyelesaikan target hafalan serta bersikap tenang dalam pembelajaran. Seperti menurut Choirul Fuad Yusuf (2008:131) bahwa nilai tanggung jawab siswa apabila siswa melaksanakan peraturan sekolah dan melaksanakan tugas- tugas yang dibebankan oleh sekolah seperti memimpin doa setelah shalat berjamaah, memberikan kultum, menghafal doa-doa, menghafal ayat-ayat Al Qur'an sedangkan sikap sopan santun juga diterapkan baik di kelas maupun dirumah.

Sholat dhuha dilakukan di dalam kelasnya masing-masing dengan di imami oleh salah satu siswa setiap kelasnya. Sholat dhuha dilaksanakan setiap hari mulai dari kelas 1 sampai kelas 6. Menjadikan suatu hal yang sudah terbiasa dilakukannya, sudah menjadi suatu kewajiban dan tangggungjawab untuk melaksanakan sholat dhuha.

Taman pendidikan Al Qur'an atau TPQ dilakukan pada siswa kelas 1 sampai dengan kelas 6 dan dilakukan pada hari senin sampai kamis. Pendidikan ini bertujuan untuk memberikan pengajaran membaca Al Qur'an sejak dini. Pada pelaksanaan TPQ tiba, guru mengkondisikan siswa agar menuju ke kelas TPQ nya masing sesuai dengan jilid maupun AlQur'an.

\section{Simpulan dan Saran}

Setelah memaparkan data tersebut, maka dapat diambil kesimpulan bahwa berdarsarkan hasil penelitian perilaku siswa dalam sehari-hari dapat dikatakan baik karena diatas rata-rata hasil dalam kategori 'Tinggi' dan 'Sedang'. Dalam penerapan budaya sekolah religius SD Muhammadiyah 17 Semarang dapat membentuk karakter siswa baik didalam kelas, diluar kelas maupun melalui keteladanan serta pembiasaan, dan program program yang dirancang dalam membentuk karakter pada siswa.

Bentuk kegiatan di SD Muhammadiyah 17 Semarang yaitu pembiasaan senyum, salam, sapa, sopan, santun atau $5 S$ melalui berjabat tangan, pembiasaan berdoa sebelum dan sesuadah pembelajaran, hafalan, TPQ, sholat dhuha, sholat dhuhur.

Dengan adanya budaya sekolah yang religius tersebut maka akan mengembangkan karakter yang ingin dicapai seperti karakter religius, disiplin, toleransi, bersahabat, kerja keras, dan tanggung jawab.

Setelah melaksanakan penelitian di SD Muhammadiyah 17 Semarang, ada beberapa saran yang perlu dikemukakan sebagai berikut: 1) Adanya budaya budaya serta program yang religius yang dilaksanakan, akan terlaksana lebih baik dan menjadi sekolah yang menjadi teladan atau contoh lembaga sekolah lainnya, 2) Melakukan inovasi dalam melaksanakan budaya religius, untuk mengurangi dan menhindari rasa bosan peserta, didik dalam melaksanakan kegiatan religious, dan 3) Kepada siswa-siswi Muhammadiyah 17 Semarang, agar lebih membiasakan budaya religius dengan lebih baik lagi.

\section{DaftarPustaka}

Choirul Fuad Yusuf. 2008. Budaya Sekolah dan Mutu Pendidikan. Jakarta. PT Pena Citasatria.

Daryanto. 2015. Pengelolaan budaya dan iklim sekolah. Yogyakarta:Penerbit Gava Media 
IVCEJ, Vol 2 No 1, Tahun 2019

p-ISSN: 2615-4684 e-ISSN: 2615-6938

Fathurrahman, Muhammad. 2015. Budaya Religius Dalam Peningkatan Mutu Pendidikan: Tinjauan Teoritik dan praktik konstektualisasi Pendidikan Agama di Sekolah. Yogyakarta: Kalimedia

Indonesia. Undang-undang Sistem Pendidikan Nasional, UU No.20 Tahun 2003. Jakarta: Sekertariat Negara.

Pradana, Yudha. 2016. Pengembangan Karakter Siswa Melalui Budaya Sekolah. Untirta Civic Education Journal, 2541-6693.

Jalaludin. 2012. Membangun SDM Bangsa Melalui Pendidikan Karakter. Jurnal Penelitian Pendidikan | Vol. 13 No. 2 Hal. 1-14.Tersedia Pada : http://jurnal.upi.edu/file/jalaludin.pdf.

Kamus Besar Bahasa Indonesia Online. http://kbbi.web.id/peran. Pada tanggal 10 November 2018 pukul 20:46 WIB.

Kamus Besar Bahasa Indonesia Online. https://kbbi.web.id/analisis. Pada tanggal 10 November 2018 pukul 20:50 WIB.

Kamus Besar Bahasa Indonesia Online. https://kbbi.web.id/karakter. Pada tanggal 10 November 2018 pukul 20:57 WIB.

Kurniasih, Imas \& Sani, Berlin. 2017. Pendidikan Karakter.Kata Pena.

Marzuki. 2017. Pendidikan karakter islam. Jakarta: Amzah.'

Najib, Muhammad, Novan Ardi Wiyani dan Solichin. 2016. Manajemen Strategik Pendidikan Karakter. Yogyakarta: Penerbit Gava Media.

Moleong, Lexy J. 2007. Metodologi Penelitian Kualitatif. Bandung: PT Remaja Rosdakarya.

Omeri, Nopan. 2015. Pentingnya Pendidikan Karakter dalam Dunia Pendidikan. Manajer Pendidikan, Volume 9, Nomor 3, Hal. 464-468. Tersedia Pada : https://media.neliti.com/media/publications/270930-pentingnya-pendidikan-karakterdalam-dun-f6628954.pdf.

Sahlan, Asmaun. 2010. Mewujudkan Budaya Religius di Sekolah. Malang: UIN Maliki Press.

Sugiyono. 2012. Metode Penelitian Kuantitatif, kualitatif, dan R\&D. Bandung: Alf abeta.2.

Teng, H. Muhammad Bahar Akkase. 2017. Filsafat Kebudayaan dan Sastra (dalam Perspektif Sejarah). Jurnal IImu Budaya Volume 5, Nomor 1, Hal.69-75. Tersedia Pada : https://media.neliti.com/media/publications/163193-ID-filsafat-kebudayaan-dan-sastradalam-per.pdf.

Undang-Undang Sistem Pendidikan Nasional Tahun 2003.

Wibowo. 2013. Budaya Organisasi. Jakarta: PT Raja Grafindo Persada.

Wiyani, Novan Ardy.Manajemen Pendidikan Karakter. Yogyakarta: PT Pustaka Insan Madani.

Yaumi, Muhammad. 2014. Pendidikan karakter: Landasan, Pilar, dan Implementasi.Jakarta: Prenamedia Group.

Yusuf, Muhammad. 2013. Membentuk Karakter Melalui Pendidikan Berbasis Nilai. Jurnal AlUlum Volume. 13 Nomor 1, Hal 1-24. Tersedia Pada : https://media.neliti.com/media/publications/195591-none-2437bc9a.pdf.

Zazin, N. 2014. Gerakan Menata Mutu Pendidikan. Yogyakarta: Ar-Ruzz Media. 